\title{
Effect of Supplementing Myristic Acid in Dairy Cow Rations on Ruminal Methanogenesis and Fatty Acid Profile in Milk
}

\author{
N. E. Odongo, ${ }^{1}$ M. M. Or-Rashid, E. Kebreab, J. France, and B. W. McBride \\ Department of Animal and Poultry Science, University of Guelph, Guelph, Ontario, Canada N1G 2W1
}

\begin{abstract}
The objective of this study was to evaluate the effects of supplementing myristic acid in dairy cow rations on ruminal methanogenesis and the fatty acid profile in milk. Twelve multiparous Holstein dairy cows (710 \pm $17.3 \mathrm{~kg}$ of live weight; $290 \pm 41.9 \mathrm{~d}$ in milk) housed in a tie-stall facility were used in the study. The cows were paired by parity and days in milk and allocated to 1 of 2 treatments: 1 ) the regular milking cow total mixed ration (control diet), and 2) the regular milking cow total mixed ration supplemented with 5\% myristic acid on a dry matter basis (MA diet). The cows were fed and milked twice daily (feeding, 0830 and $1300 \mathrm{~h}$; milking, 0500 and $1500 \mathrm{~h}$ ). The experiment was conducted as a completely randomized design and consisted of a 7-d pretrial period when cows were fed the control diet to obtain baseline measurements, a 10-d dietary adaptation period, and a 1-d, 8-h measurement period. The MA diet reduced methane $\left(\mathrm{CH}_{4}\right)$ production by $36 \%$ (608.2 vs. $390.6 \pm 56.46 \mathrm{~L} / \mathrm{d}$, control vs. MA diet, respectively) and milk fat percentage by $2.4 \%$ (4.2 vs. $4.1 \pm$ $0.006 \%$, control vs. MA diet, respectively). The MA diet increased 14:0 in milk by $139 \%$ and cis-9 $14: 1$ by $195 \%$. There was a correlation $(\mathrm{r}=-0.58)$ between the 14:0 content in milk and $\mathrm{CH}_{4}$ production and cis-9 14:1 and $\mathrm{CH}_{4}$ production $(\mathrm{r}=-0.47)$. Myristic acid had no effect on the contents of CLA or trans-10 18:1 and trans-11 18:1 isomers in milk. These results suggest that MA could be used to inhibit the activities of methanogens in ruminant animals without altering the conjugated linoleic acid and trans-18:1 fatty acid profile in milk.
\end{abstract}

Key words: dietary myristic acid, ruminal methanogenesis, milk fatty acid profile

\section{INTRODUCTION}

Methane is produced as an unavoidable by-product of OM fermentation in the rumen and represents a 2 to

Received August 18, 2006.

Accepted December 11, 2006.

${ }^{1}$ Corresponding author: nodongo@uoguelph.ca
$12 \%$ loss of gross energy intake (Johnson and Johnson, 1995). It has been estimated that an adult dairy cow produces 80 to $100 \mathrm{~kg}$ of methane $\left(\mathrm{CH}_{4}\right)$ from enteric fermentation per year (EPA, 1993). On a global basis, ruminants (sheep, goats, camels, cattle, and buffalo) produce about $80 \mathrm{Tg}$ of $\mathrm{CH}_{4}$ annually $(1 \mathrm{Tg}=1$ million metric tons), accounting for about $22 \%$ of $\mathrm{CH}_{4}$ emissions from human-related activities (NRC, 2002). Because $\mathrm{CH}_{4}$ is a potent greenhouse gas and contributes to global warming (NRC, 1992), it has a global warming potential 23 times that of $\mathrm{CO}_{2}$ (IPCC, 2001); mitigating $\mathrm{CH}_{4}$ emission from dairy cattle will have long-term environmental benefits in terms of reducing the contribution of animal agriculture to greenhouse gas emissions.

However, $\mathrm{CH}_{4}$ production in ruminants is influenced by many factors. One option to alter $\mathrm{CH}_{4}$ production is the addition of dietary fats in the ration (Czerkawski et al., 1966; Van Nevel and Demeyer, 1981; Moss et al., 2000 ), which are normally added to increase energy density, enhance milk production, or modify the fatty acid (FA) composition of milk fat (Murphy et al., 1995; Ashes et al., 1997). Among the saturated fatty acids (SFA), medium-chain fatty acids (MCFA; $\mathrm{C}_{8}$ to $\mathrm{C}_{16}$ ) are known to have the greatest potential to suppress rumen methanogenesis (Blaxter and Czerkawski, 1966) and methanogens (Henderson, 1973; Soliva et al., 2004). In in vitro studies, addition of palm kernel oil, coconut oil, and canola oil at 5\% (on a DM basis) reduced $\mathrm{CH}_{4}$ production by 34,21 , and $20 \%$, respectively (Dohme et al., 2000). When coconut oil was fed to sheep at 3.5 and $7 \%$, daily $\mathrm{CH}_{4}$ production was reduced by 28 and $73 \%$, respectively (Machmüller and Kreuzer, 1999). However, so far no reports exist on whether supplementing dairy cow rations with MCFA such as myristic acid (MA) would alter the ruminal environment markedly enough to cause milk fat depression or change the conjugated linoleic acid (CLA) and trans-18:1 FA profile in milk in addition to inhibiting ruminal methanogenesis and methanogens. We hypothesized that supplementing dairy cow rations with 5\% (on a DM basis) MA in the TMR would not alter the FA profile in milk. The objective of this study was therefore to evaluate the effects of supplementing MA in dairy cow rations on ruminal methanogenesis and the FA profile in milk. 


\section{MATERIALS AND METHODS}

\section{Animals and Experimental Design}

Twelve multiparous Holstein dairy cows $(710 \pm 17.3$ $\mathrm{kg}$ of live weight; $290 \pm 41.9 \mathrm{DIM}$ ) housed in a tie-stall facility at the Elora Dairy Research Centre, University of Guelph (Guelph, ON, Canada) were used in the study. Animals were cared for and handled in accordance with the Canadian Council on Animal Care regulations, and the University of Guelph Animal Care Committee reviewed and approved the experiment and all procedures carried out in the study. The cows were paired by parity and DIM and allocated to 1 of 2 treatments: 1) the regular milking cow TMR (control diet), and 2) the regular milking cow TMR supplemented with 5\% MA on a DM basis (MA diet). The experiment was conducted as a completely randomized block design and consisted of a 7-d pretrial period when cows were fed the control diet to obtain baseline measurements, a 10-d dietary adaptation period, and a 1-d, 8-h $\mathrm{CH}_{4}$ measurement period. The ingredient and chemical composition of the diet is presented in Table 1.

Cows were fed ad libitum (allowing for a 5 to $10 \%$ refusal) twice daily at 0830 and $1300 \mathrm{~h}$ and had unlimited access to fresh water. The cows were milked twice daily at 0500 and $1500 \mathrm{~h}$ in their stalls, and milk samples were collected daily from morning and afternoon milkings and preserved with 2-bromo-2-nitropropane1-2-diol. The morning and afternoon milk samples were pooled daily based on milk yield, and the pooled samples were immediately submitted to the Central Milk Testing Laboratory (Laboratory Services Division, University of Guelph) for compositional analysis. A second set of milk samples without preservative was also collected daily from morning and afternoon milkings and stored at $-20^{\circ} \mathrm{C}$ for milk FA analysis.

\section{Measurements of $\mathrm{CH}_{4}$ Production}

Methane production from the cows was determined using a mobile, open-circuit indirect calorimetry system as described by Kelly et al. (1994) and updated by Odongo et al. (2007). Briefly, the calorimetry unit was based on 2 separate but linked sampling lines attached to 2 airtight ventilated head-hoods. The hoods were large enough to allow the animals to move their heads without restriction such that the animals could stand or lie down in the stanchions with their heads remaining in the hoods. The animal's head was enclosed in the hood using a sleeve around the animal's neck to minimize air leakage. The cows had free access to feed and water in the hood. Outside air was circulated around the animal's head, mouth, and nose through the sleeve, and a subsample of the expired air was
Table 1. Ingredients and chemical composition (DM basis) of the diets

\begin{tabular}{lcc}
\hline Item & Control & $\begin{array}{c}\text { Myristic } \\
\text { acid }\end{array}$ \\
\hline Ingredient composition, \% (DM basis) & & \\
Hay & 5.5 & 5.2 \\
Haylage & 22.1 & 21.1 \\
Corn silage & 33.2 & 31.7 \\
High-moisture corn & 20.2 & 19.3 \\
Custom TMR dairy supplement ${ }^{1}$ & 18.9 & $22.8^{2}$ \\
Chemical composition, \% (DM basis) & & \\
CP, \% (N $\times$ 6.25) & 17.3 & 17.3 \\
Soluble protein, \% & 6.15 & 4.82 \\
Soluble protein, \% of CP & 35.3 & 28.1 \\
Undegradable protein, \% of CP & 32.4 & 35.9 \\
ADF, \% & 26.4 & 25.0 \\
NDF, \% & 40.8 & 37.8 \\
NFC & 31.4 & 34.7 \\
Lignin, \% NDF & 8.0 & 10.8 \\
Calcium, \% & 0.83 & 0.79 \\
Phosphorus, \% & 0.46 & 0.45 \\
Potassium, \% & 1.50 & 1.41 \\
Magnesium, \% & 0.25 & 0.25 \\
Sodium, \% & 0.45 & 0.46 \\
NE, Mcal/kg & 1.46 & 1.48 \\
Ether extract, \% & 3.02 & 3.22 \\
Ash, \% & 7.50 & 7.01 \\
\hline
\end{tabular}

${ }^{1}$ Provided as a mash supplement. Ingredients (\%): corn gluten meal, 210; soybean meal, 250; beet pulp, 50; herring meal, 50; canola meal, 100; roasted soybeans, 100; soybean hulls, 41; white salt, 23; dicalcium phosphate, 29; limestone, 45 ; bicarbonate, 35; magnesium oxide $(56 \% \mathrm{Mg})$, 5; Fibrozyme (Alltech Inc., Nicholasville, KY), 3; Organic Ruminant Micro Premix (Floradale Feed Mill Limited, Floradale, ON, Canada), 5; sulfur 99.5\%, 2.1; Yea-Sacc ${ }^{1026}$ (Alltech Inc.), 2; Rovimix H-2 (DSM Nutritional Products, Inc., Parsippany, NJ), 0.1; DCAD+, 159; Golden Flake (Floradale Feed Mill), 20; molasses, 20.

${ }^{2}$ Myristic acid in supplement (\%): myristic acid, 194; corn gluten meal, 170; soybean meal, 202; beet pulp, 50; herring meal, 40; canola meal, 86 ; roasted soybeans, 86 ; soybean hulls, 15 ; white salt, 18 ; dicalcium phosphate, 23; limestone, 36; bicarbonate, 28; magnesium oxide $(56 \% \mathrm{Mg}), 4$; Fibrozyme (Alltech Inc.), 2.4; Organic Ruminant Micro Premix (Floradale Feed Mill Limited), 4.7; sulfur 99.5\%, 1.9; Yea-Sacc ${ }^{1026}$ (Alltech Inc.), 1.6; Rovimix H-2 (DSM Nutritional Products, Inc.), 0.1; DCAD+, 127; Golden Flake (Floradale Feed Mill Ltd.), 15; molasses, 15.

${ }^{3}$ Nonfiber carbohydrates were calculated as NFC $=100-(\% \mathrm{NDF}$ $+\% \mathrm{CP}+\%$ fat $+\%$ ash $)$.

passed through Drierite (W. A. Hammond Drierite Co., Ltd., Xenia, OH) to remove water vapor and delivered at positive pressure to inline analyzers. Methane and $\mathrm{CO}_{2}$ concentrations in samples of inspired and expired air were measured using a nondispersive infrared $\mathrm{CH}_{4} /$ $\mathrm{CO}_{2}$ analyzer (Servomex Xentra 4100 gas purity analyzer; Servomex Group Ltd., Crowborough, East Sussex, UK), whereas the concentration of $\mathrm{O}_{2}$ was measured using a paramagnetic $\mathrm{O}_{2}$ analyzer (Servomex Xentra 4100 gas purity analyzer; Servomex Group Ltd.) with a response time of $<12 \mathrm{~s}$ for the $\mathrm{O}_{2}$ analyzer and $<20$ s for the $\mathrm{CH}_{4} / \mathrm{CO}_{2}$ analyzer. A Foxboro 823 IFO integral flow orifice with cell transmitter (Invensys Systems, Inc., Foxboro, MA) was used to measure the air- 
flow rate. The analyzers were calibrated each week as described by McLean and Tobin (1987).

\section{Chemical Analysis}

Feed intakes were monitored daily throughout the experiment. Orts from individual cows were weighed each morning prior to feeding, and representative feed and ort samples were collected 3 times per week and stored at $-20^{\circ} \mathrm{C}$ until analysis. The feed and orts were analyzed for DM by oven-drying at $60^{\circ} \mathrm{C}$ for $48 \mathrm{~h}$ (method 930.15; AOAC, 1990). Dried feed and ort samples were ground to pass through a 1-mm screen (Wiley mill; Arthur H. Thomas, Philadelphia, PA) for chemical composition determination in duplicate at a commercial laboratory (Agri-Food Laboratories, Guelph, ON, Canada). Analytical DM content was determined by ovendrying at $135^{\circ} \mathrm{C}$ for $2 \mathrm{~h}$ (method 3.002; AOAC, 1990), $\mathrm{OM}$ by ashing at $500^{\circ} \mathrm{C}$ for $16 \mathrm{~h}$ (method 942.05 ; AOAC, 1990), and CP using a Leco FP 428 nitrogen analyzer (Leco Corporation, St. Joseph, MI; method 4.2.08; AOAC, 1990). The samples were also analyzed for ether extract (method 920.39; AOAC, 1990), ADF (method 973.18c; AOAC, 1990), NDF (Van Soest et al., 1991) using $\alpha$-amylase (Sigma no. A3306; Sigma Chemical Co., St. Louis, MO), sodium sulfite corrected for ash concentration adapted for an Ankom 200 fiber analyzer (Ankom Technology, Fairport, NY), and Ca and P by inductively coupled plasma spectroscopy (method 945.46; AOAC, 1990). Milk samples were analyzed for $\mathrm{CP}$ and fat using a near-infrared analyzer (Foss System 4000; Foss Electric, Hillerød, Denmark).

\section{Analysis of FA Composition}

Frozen milk samples were thawed in a $38^{\circ} \mathrm{C}$ water bath and mixed according to AOAC method 925.21 (AOAC, 1990). Total milk fat was extracted with chloroform, methanol, and water in the ratio of 1:1:0.9 as described by Bligh and Dyer (1959). The total lipids were methylated using $\mathrm{NaOCH}_{3}$ as catalyst (Cruz-Hernandez et al., 2004) and analyzed directly by GLC. Fatty acid methyl ester analysis was performed using an Agilent 6890N GLC (Agilent Technologies, Palo Alto, CA) equipped with a split-splitless injector at $250^{\circ} \mathrm{C}$, a flame-ionization detector at $250^{\circ} \mathrm{C}$, and a $\mathrm{CP}$ Sil 88 column (100 m, $0.25 \mathrm{~mm}, 0.2 \mu \mathrm{m}$ film thickness; Varian Inc., Mississauga, ON, Canada). Hydrogen was used as carrier gas at a constant flow rate of $1 \mathrm{~mL} / \mathrm{min}$. The temperature of the GLC oven was set to $45^{\circ} \mathrm{C}$ for $4 \mathrm{~min}$, increased at $13^{\circ} \mathrm{C} / \mathrm{min}$ to $175^{\circ} \mathrm{C}$, and held for $27 \mathrm{~min}$, increased at the rate of $4^{\circ} \mathrm{C} / \mathrm{min}$ to a final temperature of $215^{\circ} \mathrm{C}$, and held for $35 \mathrm{~min}$. Agilent Technologies
Chemstation software (Rev. B.01.01) was used for data analysis. A 1- $\mu \mathrm{L}$ sample was injected at splitless mode. Peaks were routinely identified by comparison of retention times with FA methyl ester standards (GLC \#463, \#UC-59-M, 21:0, 23:0, and 26:0; NuCheck Prep Inc., Elysian, MN). The trans-11, cis-15 18:2 was identified by cross-referencing with previously published isomeric profiles reported for milk fat using cis-9, cis-12 18:2 as a landmark isomer (Ulberth and Henninger, 1994; Precht and Molkentin, 1997). Individual isomers of 18:1 FA were determined as follows: The temperature of GLC oven was maintained at $45^{\circ} \mathrm{C}$ for $4 \mathrm{~min}$, increased to $167^{\circ} \mathrm{C}$ at a rate of $13^{\circ} \mathrm{C} / \mathrm{min}$ and held for $40 \mathrm{~min}$, and again increased at the rate of $4^{\circ} \mathrm{C} / \mathrm{min}$ to a final temperature of $218^{\circ} \mathrm{C}$ and held for $23 \mathrm{~min}$. Separation of trans and cis octadecenoic acids was incomplete, but the chromatography allowed the major isomers of interest to be resolved. The trans-6, trans-7, and trans-8 18:1 isomers and the trans-13 and trans-14 18:1 isomers remained unresolved as single peaks. Individual trans isomers were identified by cross-referencing with previously published isomeric profiles reported for milk fat (Precht and Molkentin, 1997; Shingfield et al., 2003; Loor et al., 2004) using trans-11 18:1 as a landmark isomer. Fatty acid composition was expressed as grams/ 100 grams of total FA.

\section{Statistical Analysis}

Data on the response variables were analyzed using PROC MIXED of SAS (v. 9.1; SAS Institute, Cary, NC) using the model

$$
\mathrm{Y}_{\mathrm{ij}}=\mu+\alpha_{\mathrm{i}}+\beta_{\mathrm{j}}+\varepsilon_{\mathrm{ij}},
$$

where $Y_{i j}$ is the dependent variable, $\mu$ is the overall mean, $\alpha_{\mathrm{i}}$ is the effect of treatment $(\mathrm{i}=1,2), \beta_{\mathrm{j}}$ is the effect of pair $(\mathrm{j}=1,2, \ldots, 6)$, and $\varepsilon_{\mathrm{i}}$ is the random residual error. Baseline DMI was used as covariate. The correlations between $\mathrm{CH}_{4}$ production and 14:0 and $\mathrm{CH}_{4}$ production and cis-9 14:1 were determined using the Corr procedure of SAS. Effects were considered significant at a probability of $P<0.05$.

\section{RESULTS AND DISCUSSION}

\section{DMI and $\mathrm{CH}_{4}$ Production}

Dry matter intake and $\mathrm{CH}_{4}$ production are summarized in Table 2 . All animals adapted easily to confinement in the hoods during $\mathrm{CH}_{4}$ measurement, and there were no indications of discomfort or stress to the animals. Myristic acid reduced $(P<0.05) \mathrm{CH}_{4}$ production by $36 \%$ (608.2 vs. $390.6 \pm 56.46 \mathrm{~L} / \mathrm{d}$, control vs. MA diet, 
Table 2. Effects of a control vs. myristic acid-treated TMR on DMI, milk yield, milk protein, milk fat, and methane production from lactating dairy cows ${ }^{1}$

\begin{tabular}{lccc}
\hline Response & Control & $\begin{array}{c}\text { Myristic } \\
\text { acid }\end{array}$ & SEM \\
\hline DMI, kg/d & 15.2 & 14.2 & 2.84 \\
Milk yield, kg/d & 14.9 & 13.4 & 1.53 \\
Protein, \% & 3.5 & 3.6 & 0.16 \\
Fat, \% & $4.2^{\mathrm{a}}$ & $4.1^{\mathrm{b}}$ & 0.006 \\
Methane production, L/d & $608.2^{\mathrm{a}}$ & $390.6^{\mathrm{b}}$ & 56.46 \\
Methane production, MJ/d & $23.0^{\mathrm{a}}$ & $14.8^{\mathrm{b}}$ & 2.14 \\
\hline
\end{tabular}

${ }^{\mathrm{a}, \mathrm{b}}$ Means within a row with different superscripts differ $(P<0.05)$.

${ }^{1}$ Means are based on 6 cows per treatment.

respectively) consistent with previous studies. Diets containing MCFA (e.g., coconut oil) have been shown in in vitro (Dong et al., 1997; Machmüller et al., 1998) and in vivo studies (Machmüller and Kreuzer, 1999) to significantly suppress methane production in ruminants. Dohme et al. (2000) observed from in vitro studies that addition of $5.3 \%$ palm kernel oil reduced $\mathrm{CH}_{4}$ production by $34 \%$, similar to the reduction in $\mathrm{CH}_{4}$ production obtained in the current study. When coconut oil was fed to sheep at inclusion rates of 3.5 and $7 \%$, daily $\mathrm{CH}_{4}$ production was reduced by 28 and $73 \%$, respectively (Machmüller and Kreuzer, 1999). The predominant FA in coconut oil are lauric acid (average proportion approximately 47\%) and MA (18\%; Dohme et al., 2000). Machmüller et al. (2002) reported a 58\% reduction in methane production in sheep supplemented with 5\% MA.

There was a tendency $(P=0.09)$ for the MA diet to reduce DMI. This tendency to reduce DMI was not surprising because lauric acid and MA have been shown to interact with dietary fiber in the rumen to depress fiber degradability (Dohme et al., 2001; Machmüller et al., 2001). In general, adding $>5$ to $6 \%$ of fats in the ration has been shown to depress fiber degradation in the rumen (Dong et al., 1997; Mathison et al., 1998) and reduce acetate production and milk fat content (Jenkins et al., 1996; Ashes et al., 1997). These MCFA have the potential to adversely affect ruminal ciliate protozoa, several bacterial species, and methanogens (Henderson, 1973; Dohme et al., 2001; Soliva et al., 2003). Soliva et al. (2004) suggested that the initial reduction in methane production was associated with decreased fiber degradation, which Miller (1995) suggested was due to $\mathrm{H}_{2}$ accumulation; however, these microbes adapted to lauric acid and MA, in contrast to other microbes such as the methanogens and ciliate protozoa (Soliva et al., 2004).

The MA diet appeared to have no adverse effect on Butyrivibrio fibrisolvens, a cellulolytic bacteria that synthesizes mainly cis-9, trans-11 CLA from linoleic acid (Kepler et al., 1966; Kepler and Tove, 1967; Kim et al., 2000) and, as a result, did not shift the high production of trans-10 18:1 from linoleic acid via trans10, cis-12 CLA, as shown in Table 4. Methanogenesis has also been inhibited as a direct toxic effect of unsaturated FA on methanogens (e.g., Prins et al., 1972; Henderson, 1973). Unsaturated FA have no effect on gramnegative bacteria (e.g., Megasphaera elsdenii, Selenomonas ruminantium, or Prevotella ruminicola) but inhibit gram-positive or gram-positive-type cell wall bacteria (e.g., B. fibrisolvens, Ruminococcus albus, and Ruminococcus flavefaciens; Henderson, 1973; Maczulak et al., 1981). Schonhusen et al. (2003) showed that methanogenesis in the rumen, and not in the hindgut, was associated with the development of protozoal populations. Because virtually all bacteria attached to protozoa are methanogens (Vogels et al., 1980), by removing the protozoal population through defaunation, the ruminal bacterial population is modified, VFA production is shifted from acetate and butyrate toward propionate, and $\mathrm{CH}_{4}$ production is reduced (Hegarty, 1999).

\section{Milk Yield and Components}

Milk yield and milk components are presented in Table 2 . The MA diet reduced $(P<0.05)$ milk fat percentage by $2.4 \%$ but had no effect $(P>0.05)$ on milk yield. Myristic acid had no $(P>0.05)$ effect on milk protein percentage, although milk protein depression (lower protein percentage but not necessarily protein production) has been associated with the feeding of supplemental dietary fat to dairy cows (DePeters and Cant, 1992; Wu and Huber, 1994). The total yields of milk fat and protein were 638.6 vs. $485.0 \pm 73.08 \mathrm{~g} / \mathrm{d}$ and 520.9 vs. $414.4 \pm 45.85 \mathrm{~g} / \mathrm{d}$, control vs. MA diet, respectively.

Because the cows used in the current study were in late lactation ( $290 \pm 41.9 \mathrm{DIM})$, this raised the question of how much the benefit of lower $\mathrm{CH}_{4}$ would be compromised by the need to maintain more animals to obtain equal yield. Kirchgessner et al. (1995) estimated that although increasing milk production from 5,000 to $10,000 \mathrm{~L} / \mathrm{yr}$ would increase total $\mathrm{CH}_{4}$ production per cow per year by $23 \%$ (i.e., from 110 to $135 \mathrm{~kg} / \mathrm{yr}$ ), $\mathrm{CH}_{4}$ production per kilogram of milk would be reduced by $40 \%$ (i.e., from 0.022 to $0.014 \mathrm{~kg}$ of $\mathrm{CH}_{4} / \mathrm{kg}$ of milk). Therefore, overall $\mathrm{CH}_{4}$ production could be decreased by reducing animal numbers while maintaining milk production.

\section{Milk FA Composition}

Milk FA including 18:1 isomers are summarized in Tables 3 and 4 . The MA diet increased $(P<0.05)$ 14:0 
in milk by $139 \%$ and cis-9 $14: 1$ by $195 \%$ compared with the control diet (Table 3). Palmitic acid (16:0) was $23 \%$ higher $(P<0.05)$ in the control group than in the MA group, whereas stearic acid (18:0) was $43 \%$ lower $(P<$ 0.05 ) in the MA group compared with the control group. The increased proportion of MA in milk fat decreased the proportions of palmitic and stearic acids in the MA group compared with the control group. However, if excessive amounts of long-chain SFA were incorporated in milk fat, it would cause milk fat to solidify. Because the melting points of short-chain SFA and MCFA are lower than those of long-chain SFA, the synthesis and supply of short-chain SFA and MCFA in the mammary tissue to modify milk fat fluidity is therefore critical. The increased level of MA in milk fat of the MA group in the current study would therefore give better fluidity than the control diet. Although total SFA were not $(P$ $>0.05$ ) affected by dietary treatment, the concentration of long-chain SFA (16:0 to 26:0) in the MA group were 2 -fold lower $(P<0.05)$ than in the control group.

The contents of odd-chain SFA 19:0 and 21:0 were lower $(P<0.05)$ in the MA group compared with the control group (Table 3 ). The concentration of branchedchain SFA iso-14:0, anteiso-15:0, and iso-16:0 were lower $(P<0.05)$ in the MA group compared with the control group. Odd- and branched-chain FA in milk are synthesized by microbes in the rumen and are generally rare or absent in feeds (Diedrich and Henschel, 1990). These odd- and branched-chain FA can make up to 1.0 to $3.0 \%$ of milk and carcass lipids (Alonso et al., 1999; Bas and Morand-Fehr, 2000). The contents of these FA in a ruminant animal's milk or meat is therefore considered a reflection of microbial activities in the rumen. The difference in FA content (i.e., odd- and branched-chain FA) between the 2 groups suggests that MA supplementation must have altered the activities of some groups of microbes in the rumen. Bas et al. (2003) and Vlaeminck et al. (2006) have also reported that odd- and branched-chain FA contents in mixed rumen bacteria were changed with dietary differences.

Linoleic acid was the highest polyunsaturated FA in both the control and MA-treated group, followed by linolenic acid (Table 3). Myristic acid-supplemented cows had $22 \%$ lower $(P<0.05)$ linoleic acid concentrations in their milk than did the control group. The concentration of trans-9, cis-12 18:2 and trans-11, cis-15 18:2 were not $(P>0.05)$ affected by dietary treatment. The milk of the MA-treated cows had 56\% lower $(P<$ 0.05) nervonic acid (cis-15 24:1) than did the control group, although the concentration was very low in both groups. The concentration of highly unsaturated FA such as arachidonic acid (20:4), eicosapentaenoic acid (20:5n-3), and docosahexaenoic acid (22:6n-3) were not
Table 3. Effects of a control vs. myristic acid-treated TMR on milk fatty acid contents $(\mathrm{g} / 100 \mathrm{~g}$ of fatty acid) in lactating dairy cows

\begin{tabular}{|c|c|c|c|}
\hline Fatty acid ${ }^{1}$ & Control & Myristic acid & SEM \\
\hline $6: 0$ & $1.74^{\mathrm{a}}$ & $1.35^{\mathrm{b}}$ & 0.066 \\
\hline 8:0 & $0.920^{\mathrm{a}}$ & $0.659^{b}$ & 0.0768 \\
\hline 10:0 & 2.88 & 2.35 & 0.222 \\
\hline 11:0 & 0.312 & 0.292 & 0.0244 \\
\hline $12: 0$ & 3.59 & 3.17 & 0.338 \\
\hline ai-13:0 & 0.090 & 0.086 & 0.0093 \\
\hline $12: 1$ & 0.092 & 0.095 & 0.0066 \\
\hline $13: 0$ & 0.101 & 0.108 & 0.0131 \\
\hline iso-14:0 & $0.211^{\mathrm{a}}$ & $0.068^{\mathrm{b}}$ & 0.0175 \\
\hline $14: 0$ & $12.8^{\mathrm{a}}$ & $30.6^{\mathrm{b}}$ & 0.73 \\
\hline iso-15:0 & 0.229 & 0.197 & 0.0204 \\
\hline ai-15:0 & $0.501^{\mathrm{a}}$ & $0.321^{\mathrm{b}}$ & 0.0249 \\
\hline Cis-9 14:1 & $0.97^{\mathrm{a}}$ & $2.86^{\mathrm{b}}$ & 0.135 \\
\hline $15: 0$ & 1.28 & 1.25 & 0.055 \\
\hline iso- $16: 0$ & $0.500^{\mathrm{a}}$ & $0.227^{\mathrm{b}}$ & 0.0357 \\
\hline $16: 0$ & $31.3^{\mathrm{a}}$ & $25.4^{\mathrm{b}}$ & 0.02 \\
\hline iso- $17: 0$ & 0.281 & 0.265 & 0.0195 \\
\hline Trans-9 16:1 & 0.065 & 0.068 & 0.0090 \\
\hline ai-17:0 & 0.608 & 0.548 & 0.0232 \\
\hline Cis-9 16:1 & 1.45 & 1.39 & 0.080 \\
\hline $17: 0$ & 0.452 & 0.319 & 0.0202 \\
\hline 18:0 & $12.0^{\mathrm{a}}$ & $6.8^{\mathrm{b}}$ & 0.66 \\
\hline $19: 0$ & $0.038^{\mathrm{a}}$ & $0.016^{\mathrm{b}}$ & 0.0026 \\
\hline Trans-9, cis-12 18:2 & 0.042 & 0.066 & 0.0129 \\
\hline Trans-11, cis-15 18:2 & 0.039 & 0.037 & 0.0037 \\
\hline $18: 2 \mathrm{n}-6$ & $2.32^{\mathrm{a}}$ & $1.81^{\mathrm{b}}$ & 0.144 \\
\hline $20: 0$ & $0.208^{\mathrm{a}}$ & $0.097^{\mathrm{b}}$ & 0.0071 \\
\hline $18: 3 n-6$ & 0.027 & 0.027 & 0.0029 \\
\hline Cis-9 20:1 & $0.156^{\mathrm{a}}$ & $0.087^{\mathrm{b}}$ & 0.0062 \\
\hline Cis-11 20:1 & 0.084 & 0.065 & 0.0062 \\
\hline $18: 3 n-3$ & $0.399^{\mathrm{a}}$ & $0.259^{\mathrm{b}}$ & 0.0258 \\
\hline $21: 0$ & $0.035^{\mathrm{a}}$ & $0.020^{\mathrm{b}}$ & 0.0021 \\
\hline $20: 2 n-6$ & 0.030 & 0.024 & 0.0035 \\
\hline $22: 0$ & $0.089^{\mathrm{a}}$ & $0.030^{\mathrm{b}}$ & 0.0041 \\
\hline $20: 3 n-6$ & 0.100 & 0.095 & 0.0088 \\
\hline Cis-13 22:1 & 0.162 & 0.144 & 0.0013 \\
\hline $20: 3 n-3$ & 0.006 & 0.007 & 0.0007 \\
\hline $20: 4 n-6$ & 0.127 & 0.149 & 0.0088 \\
\hline $23: 0$ & 0.029 & 0.016 & 0.0041 \\
\hline $20: 4 n-3$ & 0.033 & 0.024 & 0.0038 \\
\hline $22: 2 n-6$ & 0.011 & 0.008 & 0.0018 \\
\hline $24: 0$ & $0.043^{\mathrm{a}}$ & $0.014^{\mathrm{b}}$ & 0.0043 \\
\hline $20: 5 n-3$ & 0.051 & 0.046 & 0.0059 \\
\hline Cis-15 24:1 & $0.009^{\mathrm{a}}$ & $0.004^{b}$ & 0.0011 \\
\hline $22: 4 n-6$ & 0.025 & 0.020 & 0.0015 \\
\hline $22: 4 n-3$ & 0.006 & 0.004 & 0.0006 \\
\hline $26: 0$ & 0.029 & 0.017 & 0.0059 \\
\hline $22: 5 n-3$ & 0.068 & 0.081 & 0.0063 \\
\hline $22: 6 n-3$ & 0.058 & 0.051 & 0.0075 \\
\hline Total CLA ${ }^{2}$ & 0.49 & 0.47 & 0.135 \\
\hline Total SFA ${ }^{3}$ & 68.8 & 72.5 & 1.23 \\
\hline $\mathrm{MCSFA}^{4}$ & $51.9^{\mathrm{a}}$ & $62.6^{\mathrm{b}}$ & 0.91 \\
\hline $\operatorname{LCSFA}^{5}$ & $14.1^{\mathrm{a}}$ & $7.9^{\mathrm{b}}$ & 0.65 \\
\hline Total MUFA ${ }^{6}$ & 27.4 & 24.0 & 0.86 \\
\hline Total n-6 PUFA ${ }^{7}$ & 3.33 & 2.96 & 0.484 \\
\hline Total n-3 PUFA ${ }^{8}$ & 0.891 & 0.771 & 0.0793 \\
\hline Total trans-18:1 & 2.75 & 2.64 & 0.333 \\
\hline Total cis-18:1 & $21.9^{\mathrm{a}}$ & $16.7^{\mathrm{b}}$ & 0.65 \\
\hline
\end{tabular}

${ }^{\mathrm{a}, \mathrm{b}}$ Means within a row with different superscripts differ $(P<0.05)$.

${ }^{1}$ Means are based on 6 cows per treatment.

${ }^{2}$ Total conjugated linoleic acid (CLA): cis-9, trans-11 18:2; cis-10, trans-12 18:2; trans-9, cis-11 18:2; trans-10, cis-12 18:2; trans-11, trans-13 18:2; trans9, trans-11 18:2; and trans-10, trans-12 18:2.

${ }^{3}$ Total saturated fatty acids (SFA): all fatty acids without any double bond (9:0 to $26: 0)$.

${ }^{4}$ MCSFA: medium-chain SFA (9:0 to 16:0)

${ }^{5}$ LCSFA: long-chain SFA (17:0 to 26:0).

${ }^{6}$ Total monounsaturated fatty acids (MUFA): all fatty acids with a single double bond (16:1 to $24: 1$ ).

${ }^{7}$ Total n-6 polyunsaturated fatty acids (PUFA): trans-9, trans-12 18:2; cis-9, trans-12 18:2; trans-9, cis-12 18:2; 18:2n-6; 18:3n-6; 20:2n-6; 20:3n-6; 22:2n-6; and $22: 5 n-6$.

${ }^{8}$ Total n-3 PUFA: 18:3n-3; 20:3n-3; 20:4n-3; and 22:4n-3. 
Table 4. Effects of a control vs. myristic acid-treated TMR on milk $18: 1$ isomers ( $\mathrm{g} / 100 \mathrm{~g}$ of fatty acid) in lactating dairy cows

\begin{tabular}{lccc}
\hline Fatty acid $^{1}$ & Control & $\begin{array}{c}\text { Myristic } \\
\text { acid }\end{array}$ & SEM \\
\hline Trans-4 18:1 & $0.015^{\mathrm{a}}$ & $0.009^{\mathrm{b}}$ & 0.0012 \\
Trans-5 18:1 & $0.011^{\mathrm{a}}$ & $0.008^{\mathrm{b}}$ & 0.0007 \\
Trans-6-8 18:1 & $0.206^{\mathrm{a}}$ & $0.153^{\mathrm{b}}$ & 0.0122 \\
Trans-9 18:1 & $0.319^{\mathrm{a}}$ & $0.242^{\mathrm{b}}$ & 0.0169 \\
Trans-10 18:1 & 0.338 & 0.312 & 0.0452 \\
Trans-11 18:1 & 0.972 & 0.867 & 0.1262 \\
Trans-12 18:1 & $0.409^{\mathrm{a}}$ & $0.315^{\mathrm{b}}$ & 0.0244 \\
Trans-13-14 18:1 & 0.300 & 0.324 & 0.0222 \\
Cis-9 18:1 & $18.8^{\mathrm{a}}$ & $14.3^{\mathrm{b}}$ & 0.94 \\
Cis-11 18:1 & 1.24 & 1.16 & 0.078 \\
Cis-12 18:1 $18: 1$ & $0.329^{\mathrm{a}}$ & $0.252^{\mathrm{b}}$ & 0.0231 \\
Cis-13 18:1 & $0.025^{\mathrm{a}}$ & $0.063^{\mathrm{b}}$ & 0.0058 \\
Trans-16 18:1 & $0.168^{\mathrm{a}}$ & $0.096^{\mathrm{b}}$ & 0.0099 \\
\hline
\end{tabular}

${ }^{\mathrm{a}, \mathrm{b}}$ Means within a row with different superscripts differ $(P<0.05)$.

${ }^{1}$ Means are based on 6 cows per treatment.

$(P>0.05)$ affected by diet. The $18: 1$ isomers in milk are presented in Table 4. The concentration of cis-9 18:1 was highest among the monounsaturated FA in both groups. Total cis-18:1 was lower $(P<0.05)$ in the MA group than in the control group. The concentration of cis-9 18:1 in the MA group was 24\% lower $(P<0.05)$ than in the control group. Other cis-18:1 FA, such as cis-12, cis-13, were also lower $(P<0.05)$ in the MA group, except for cis-11 (Table 4). Dietary supplementation with MA did not $(P>0.05)$ alter the concentration of trans-11 18:1 or trans-10 18:1 in the milk. The concentration of trans-10 18:1 was 3 times lower than the concentration of trans-11 18:1 in both groups. Myristic acid supplementation did not shift the ruminal microbial population significantly to produce more trans-10 18:1 from linoleic acid via trans-10, cis-12 CLA. Vaccenic acid was the main trans-18:1 isomer in both groups (Table 4). The milk FA profiles of cows fed diets high in unsaturated FA oils are characterized by higher levels of trans-10 18:1 compared with trans-11 18:1 (Pottier et al., 2006) because the oils induce a shift in the ruminal biohydrogenation process, resulting in the production of a higher amount of trans-10 18:1 in the mammary gland, thus causing milk fat depression. Bauman and Griinari (2003) showed that marked milk fat depression was associated with an increase in the milk fat content of the trans-10 18:1 isomer.

Total CLA contents in the milk did not $(P>0.05)$ differ between treatments (Table 3). The most abundant CLA was cis-9, trans-11 CLA, which constituted 83.3 to $85 \%$ of the total CLA content (data not shown). Trans-10, cis-12 CLA, which is known to be a potent inhibitor of milk fat synthesis (Baumgard et al., 2000), accounted for only 2 to $2.3 \%$ of total CLA. The concentrations of both cis-9, trans-11 CLA and trans-10, cis-12 CLA in milk were not affected by dietary treatment.

\section{CONCLUSIONS}

Dietary supplementation with MA reduced methane production from dairy cows but had no effect on DMI, milk yield, total CLA, or cis-9, trans-11 CLA compared with the control group. Generally, supplementation with unsaturated FA from oil shifts the production of vaccenic acid (trans-11 18:1) in the rumen toward trans10 18:1, resulting in a higher level of trans-10 18:1 in milk; however, this phenomenon was not observed with MA in the current study. These results suggest that MA could be used to inhibit the activities of methanogens in ruminant animals without altering the CLA and trans18:1 FA profiles in milk.

\section{ACKNOWLEDGMENTS}

The authors thank Laura Wright and the staff at the Elora Dairy Research Centre, University of Guelph, for their technical assistance and the Dairy Farmers of Canada (Greenhouse Gas Mitigation Program for Canadian Agriculture) for financial support. We also acknowledge the continued support received from the Ontario Ministry of Agriculture, Food and Rural Affairs and the Natural Sciences and Engineering Research Council of Canada (BWM).

\section{REFERENCES}

Alonso, L., J. Fontecha, L. Lozada, M. J. Fraga, and M. Juárez. 1999. Fatty acid composition of caprine milk: Major, branched-chain, and trans fatty acids. J. Dairy Sci. 82:878-884.

Ashes, J. R., S. K. Gulati, and T. W. Scott. 1997. New approaches to changing milk composition: Potential to alter the content and composition of milk fat through nutrition. J. Dairy Sci. 80:2204-2212.

AOAC. 1990. Official Methods of Analysis. 15th ed. AOAC, Arlington, VA.

Bas, P., H. Archimède, A. Rouzeau, and D. Sauvant. 2003. Fatty acid composition of mixed-rumen bacteria: Effect of concentration and type of forage. J. Dairy Sci. 86:2940-2948.

Bas, P., and P. Morand-Fehr. 2000. Effect of nutritional factors on fatty acid composition of lamb fat deposits. Livest. Prod. Sci. 64:61-79.

Bauman, D. E., and J. M. Griinari. 2003. Nutritional regulation of milk fat synthesis. Annu. Rev. Nutr. 23:203-227.

Baumgard, L. H., B. A. Corl, D. A. Dwyer, A. Saebo, and D. E. Bauman. 2000. Identification of the conjugated linoleic acid isomer that inhibits milk fat synthesis. Am. J. Physiol. 278:R179-R184.

Blaxter, K. L., and J. Czerkawski. 1966. Modification of the methane production of the sheep by supplementation of its diet. J. Sci. Food Agric. 17:417-421.

Bligh, E. G., and W. J. Dyer. 1959. A rapid method of total lipid extraction and purification. Can. J. Biochem. Physiol. 37:911-917.

Cruz-Hernandez, C., Z. Deng, J. Zhou, A. R. Hill, M. P. Yurawecz, P. Delmonte, M. M. Mossoba, M. E. R. Dugan, and J. K. G. Kramer. 2004. Methods for analysis of conjugated linoleic acids and trans18:1 isomers in dairy fats by using a combination of gas chromatography, silver-ion thin-layer chromatography/gas chromatography, and silver-ion liquid chromatography. J. AOAC Int. 87:545-562.

Czerkawski, J. W., K. L. Blaxter, and F. W. Wainman. 1966. The metabolism of oleic, linoleic and linolenic acids by sheep with 
reference to their effects on methane production. Br. J. Nutr. 20:349-362.

DePeters, E. J., and J. P. Cant. 1992. Nutritional factors influencing the nitrogen composition of bovine milk: A review. J. Dairy Sci. 75:2043-2070.

Diedrich, M., and K. P. Henschel. 1990. The natural occurrence of unusual fatty acids. 1. Odd numbered fatty acids. Nahrung 34:935-943.

Dohme, F., A. Machmüller, A. Wasserfallen, and M. Kreuzer. 2001. Ruminal methanogenesis as influenced by individual fatty acids supplemented to complete ruminant diets. Lett. Appl. Microbiol. 32:47-51.

Dohme, F., A. Machmüller, A. Wasserfallen, and M. Kreuzer. 2000. Comparative efficiency of various fats rich in medium chain fatty acids to suppress ruminal methanogenesis as measured with RUSITEC. Can. J. Anim. Sci. 80:473-482.

Dong, Y., H. D. Bae, T. A. McAllister, G. W. Mathison, and K. J. Cheng. 1997. Lipid-induced depression of methane production and digestibility in the artificial rumen system (RUSITEC). Can. J. Anim. Sci. 77:269-278.

EPA (US Environmental Protection Agency). 1993. Anthropogenic methane emissions in the United States: Estimates for 1990 Report to Congress. EPA 430-R-93-003. US Environmental Protection Agency, Washington, DC.

Hegarty, R. S. 1999. Reducing rumen methane emissions through elimination of rumen protozoa. Aust. J. Agric. Res. 50:1321-1327.

Henderson, C. 1973. The effect of fatty acids on pure cultures of rumen bacteria. J. Agric. Sci. 81:107-112.

IPCC (Intergovernmental Panel on Climate Change). 2001. Climate change 2001: Synthesis report. A contribution of Working Groups I, II, and III to the third assessment report of the Intergovernmental Panel on Climate Change. Cambridge Univ. Press, Cambridge, UK

Jenkins, T. C., H. G. Bateman, and S. M. Block. 1996. Butylsoyamide increases unsaturation of fatty acids in plasma and milk of lactating dairy cows. J. Dairy Sci. 79:585-590.

Johnson, K. A., and D. E. Johnson. 1995. Methane emissions from cattle. J. Anim. Sci. 73:2483-2492.

Kelly, J. M., B. Kerrigan, L. P. Milligan, and B. W. McBride. 1994. Development of a mobile, open-circuit indirect calorimetry system. Can. J. Anim. Sci. 74:65-71.

Kepler, C. R., and S. B. Tove. 1967. Biohydrogenation of unsaturated fatty acids. J. Biol. Chem. 242:5686-5692.

Kepler, C. R., K. P. Hirons, J. J. McNeill, and S. B. Tove. 1966. Intermediates and products of the biohydrogenation of linoleic acid by Butyrivibrio fibrisolvens. J. Biol. Chem. 241:1350-1354.

Kim, Y. J., R. H. Liu, D. R. Bond, and J. B. Russell. 2000. Effect of linoleic acid concentration on conjugated linoleic acid production by Butyrivibrio fibrisolvens A38. Appl. Environ. Microbiol. 66:5226-5230

Kirchgessner, M., W. Windisch, and H. L. Muller. 1995. Nutritional factors for the quantification of methane production. Pages 333348 in Ruminant Physiology: Digestion, Metabolism, Growth and Reproduction. Proc. 8th Int. Symp. Rumin. Physiol. W. Von Engelhardt, S. Leonhard-Marek, G. Breves, and D. Giesecke, ed. Ferdinand Enke Verlag, Stuttgart, Germany.

Loor, J. J., K. Ueda, A. Ferlay, Y. Chilliard, and M. Doreau. 2004. Biohydrogenation, duodenal flow, and intestinal digestibility of trans fatty acids and conjugated linoleic acids in response to dietary forage: Concentrate ratio and linseed oil in dairy cows. J. Dairy Sci. 87:2472-2485.

Machmüller, A., C. R. Soliva, R. Razminowicz, S. J. Duleba, and M. Kreuzer. 2002. Evaluating the dietary pre-conditions for a significant methane-suppressing effect of myristic acid in ruminants. Pages 155-159 in Greenhouse Gases and Animal Agriculture. J. Takahashi and B. A. Young, ed. Elsevier Science, Amsterdam, the Netherlands.

Machmüller, A., F. Dohme, C. R. Soliva, M. Wanner, and M. Kreuzer. 2001. Diet composition affects the level of ruminal methane suppression by medium-chain fatty acids. Aust. J. Agric. Res. 52: $713-722$.
Machmüller, A., and M. Kreuzer. 1999. Methane suppression by coconut oil and associated effects on nutrient and energy balance in sheep. Can. J. Anim. Sci. 79:65-72.

Machmüller, A., D. A. Ossowski, M. Wanner, and M. Kreuzer. 1998 Potential of various fatty feeds to reduce methane release from rumen fermentation in vitro (RUSITEC). Anim. Feed Sci. Technol. 71:117-130.

Maczulak, A. E., B. A. Dehority, and D. L. Palmquist. 1981. Effects of long-chain fatty acids on growth of rumen bacteria. Appl. Environ. Microbiol. 42:856-862.

Mathison, G. W., E. K. Okine, T. A. McAllister, Y. Dong, J. Galbraith, and O. I. N. Dmytruk. 1998. Reducing methane emissions from ruminant animals. J. Applied Anim. Res. 14:1-28.

McLean, J. A., and G. Tobin. 1987. Animal and Human Calorimetry. Cambridge University Press, New York, NY.

Miller, T. L. 1995. Ecology of methane production and hydrogen sink in the rumen. Pages 317-331 in Ruminant Physiology: Digestion, Metabolism, Growth and Reproduction. Proc. 8th Int. Symp. Rumin. Physiol. W. Von Engelhardt, S. Leonhard-Marek, G. Breves, and D. Giesecke, ed. Ferdinand Enke Verlag, Stuttgart, Germany.

Moss, A. R., J. P. Jouany, and J. Newbold. 2000. Methane production by ruminants: Its contribution to global warming. Annal Zootech. 49:231-253.

Murphy, J. J., J. F. Connolly, and G. P. McNeill. 1995. Effects on milk fat composition and cow performance of feeding concentrates containing full fat rapeseed and maize distillers' grains on grasssilage based diets. Livest. Prod. Sci. 44:1-11.

NRC. 1992. Policy Implications of Greenhouse Warming: Mitigation, Adaptation, and the Science Base. National Academy Press, Washington, DC.

NRC. 2002. The Scientific Basis for Estimating Air Emissions from Animal Feeding Operations. National Academy Press, Washington, DC.

Odongo, N. E., O. AlZahal, J. E. Las, A. Kramer, B. Kerrigan, E. Kebreab, J. France, and B. W. McBride. 2007. Data capture: Development of a mobile open-circuit ventilated hood system for measuring real-time gaseous exchange in cattle. In Mathematica Modeling in Animal Nutrition. J. France and E. Kebreab, ed. CABI Publishing, Wallingford, UK. (In press)

Pottier, J. M., C. Focant, G. Debier, C. De Buysser, E. Goffe, E. Mignolet, E. Froidmont, and Y. Larondelle. 2006. Effect of dietary vitamin $\mathrm{E}$ on rumen biohydrogenation pathways and milk fat depression in dairy cows fed high-fat diets. J. Dairy Sci. 89:685-692.

Precht, D., and J. Molkentin. 1997. Trans-geometric and positional isomers of linoleic acid including conjugated linoleic acid (CLA) in German milk and vegetables fats. Lipids 99:319-326.

Prins, R. A., C. J. Van Nevel, and D. I. Demeyer. 1972. Pure culture studies of inhibitors for methanogenic bacteria. Ant. Van. Leeuwen. 38:281-287.

Schonhusen, U., R. Zitnan, S. Kuhla, W. Jentsch, M. Derno, and J. Voigt. 2003. Effects of protozoa on methane production in rumen and hindgut of calves around time of weaning. Arch. Tierernahr. $57: 279-295$

Shingfield, K. J., S. Ahvenjrvi, V. Toivonen, A. Ärölä, K. V. V. Nurmela, P. Huhtanen, and J. M. Griinari. 2003. Effect of fish oil on biohydrogenation of fatty acids and milk fatty acid content in cows. Anim. Sci. 77:165-179.

Soliva, C. R., I. K. Hindrichsen, L. Meile, M. Kreuzer, and A. Machmüller. 2003. Effects of mixtures of lauric and myristic acid on rumen methanogens and methanogenesis in vitro. Lett. Appl. Microbiol. 37:35-39.

Soliva, C. R., L. Meile, A. Cieślak, M. Kreuzer, and A. Machmüller. 2004. Rumen simulation technique study on the interactions of dietary lauric and myristic acid supplementation in suppressing ruminal methanogenesis. Br. J. Nutr. 92:689-700.

Ulberth, F., and M. Henninger. 1994. Quantitation of trans fatty acids in milk fat using spectroscopic and chromatographic methods. J. Dairy Res. 61:517-527. 
Van Nevel, C. J., and D. I. Demeyer. 1981. Effect of methane inhibitors on the metabolism of rumen microbes in vitro. Arch. Tierernahr. 31:141-151.

Van Soest, P. J., J. B. Robertson, and B. A. Lewis. 1991. Methods for dietary fiber, neutral detergent fiber, and nonstarch polysaccharides in relation to animal nutrition. J. Dairy Sci. 74:35833597.

Vlaeminck, B., V. Fievez, D. Demeyer, and R. J. Dewhurst. 2006 Effect of forage:concentrate ratio on fatty acid composition of rumen bacteria isolated from ruminal and duodenal digesta. J. Dairy Sci. 89:2668-2678.

Vogels, G. D., W. F. Hoppe, and C. K. Stumm. 1980. Association of methanogenic bacteria with rumen ciliates. Appl. Environ. Microbiol. 40:608-612.

Wu, Z., and J. T. Huber. 1994. Relationship between dietary fat supplementation and milk protein concentration in lactating cows: A review. Livest. Prod. Sci. 39:141-155. 